\title{
LITERASI DIGITAL: KONTRIBUSI DAN TANTANGAN DALAM KETERAMPILAN MENULIS
}

\author{
Jonter Pandapotan Sitorus \\ Universitas Pelita Harapan \\ Jonter.sitorus@uph.edu
}

\begin{abstract}
ABSTRAK: Kajian literasi semakin sering dibicarakan khususnya literasi digital yang sering juga dikaitkan dengan keterampilan menulis. hal itu karena sejatinya menulis adalah suatu usaha untuk menuangkan ide atau sebuah gagasan kepada orang lain. Penuangan ide itu tidak terlepas dari kemampuan seseorang dalam menulis yang harus mempertimbangkan integritas dalam tulisannya. Namun, di tengah-tengah perkembangan teknologi dan informasi saat ini, kegiatan menulis justru memberikan kontribusi dan sekaligus tantangan bagi para calon penulis. Kontribusi yang dimaksud utamanya menyediakan sumber-sumber yang dapat memperkaya ide dalam penulisan. Sebaliknya, tantangan yang dimaksud dapat berupa (1) iidak ada niat atau gairah menulis, (2) ada niat, tetapi selalu merasa tidak tepat waktunya untuk menulis, (3) merasa tidak tahu apa yang akan ditulis (tataran ide), (4) takut salah, merasa tidak bermutu (tataran teknis dan konten), (5) pengaruh perhatian terhadap hal-hal yang tidak produktif, (6) tidak dapat memanfaatkan teknologi secara tepat guna.Khususnya jika tulisan itu berkategori tulisan karya ilmiah. Oleh karena itu, calon penulis harus diperkenalkan bagaimana menggunakan konsep literasi digital dalam mengembangkan ide-ide dalam tulisan yang sekaligus mengajarkan mereka untuk mampu menghasilkan tulisan-tulisan yang bermanfaat bagi para pembacanya melalui penentuan sitasi yang tepat.

Kata Kunci: literasi digital, kontribusi dan tantangan, keterampilan menulis
\end{abstract}

\section{DIGITAL LITERACY: CONTRIBUTION AND CHALLENGES IN WRITING SKILLS}

\begin{abstract}
Literacy studies are increasingly being discussed, especially digital literacy which is often also associated with writing skills. that is because writing is an attempt to express an idea or an idea to others. The pouring of ideas is inseparable from the ability of someone in writing who must consider the integrity in their writing. However, amid current technological and information developments, writing activities contribute and challenge the aspiring writers. The intended contribution is mainly to provide resources that can enrich ideas in writing. Conversely, the challenges in question can be in the form of (1) no intention or enthusiasm to write, (2) there is an intention, but always feel it is not time to write, (3) feel does not know what to write (level of ideas), (4) fear of being wrong, feeling inferior (technical level and content), (5) the effect of attention on unproductive matters, (6) not being able to utilize technology appropriately. Specifically, if the writing is categorized as scientific writing. Therefore, prospective writers should be introduced to how to use the concept of digital literacy in developing ideas in writing which at the same time teach them to be able to produce writings that are useful for their readers through the determination of appropriate citations.
\end{abstract}

Keywords: digital literacy, contributions, and challenges, writing skill 


\section{PENDAHULUAN}

Berkaca dari pengalaman penulis sebagai dosen, fakta bahwa kebanyakan mahasiswa akan terlihat antipati ketika mendengar tugas untuk menulis atau halhal yang berkaitan dengan tulis-menulis. Situasi itu terlihat saat topik menulis itu diarahkan dalam bingkai atau kerangka menulis karya ilmiah atau yang sering juga dikenal dengan sebutan karya tulis ilmiah (KTI).Gambaran situasi itu memberikan penjelasan bahwa memang kenyataannya mahasiswa pun banyak yang mengalami kesulitan di dalam menulis. Barangkali level sekelas mahasiswa dapat menjadi indikator penting yang menunjukkan bahwa secara umum pembelajar di Indonesia benar-benar mengalami kesulitan dalam menulis.

Hal itu tampaknya menjadi sebuah kontradiksi dengan kemajuan teknologi saat ini.Kemajuan teknologi yang sangat menyuguhkan ratusan atau bahkan ribuan informasi.Oleh karena itu, banyaknya informasi saat ini sering disebutkan dengan istilah "banjir infromasi".Bahkan perkembangan teknologi yang sudah berbasis digital serta masuknya era revolusi 4.0 yang diharapkan mampu mengubah cara kerja dan perolehan data di dalam setiap sendi kehidupan manusia. Kemajuan teknologi, harapannya atau idealnya kemudahan untuk menulis itu tidak menjadi suatu penghalang lagi.Akan tetapi, seharusnya keberadaan teknologi itu memberikan kontribusi penting bagi calon-calon penulis yang membantu setiap pengembangan ide dan terlebih penemuan-penemuan sumbersumber tulisan yang terpercaya.Namun, justru yang terjadi saat ini adalah sebuah ironi.Artinya, kenyataannya memang tidak selamanya perkembangan teknologi saat ini berkorelasi langsung terhadap keberhasilan menulis. Hal apa yang menyebabkan itu? Di sinilah diperlukan penyelidikan penting apa faktor-faktor yang menjadi pemberi sumbangsih sehingga menulis sangat sulit dilakukan atau menulis justru mudah dilakukan. Oleh karena itu, tulisan ini akan diarahkan untuk memberi penyelidikan terhadap permasalahan yang telah disebutkan.

Adapun fokus dari tulisan ini adalah penggalian terhadap sejauh mana literasi digital yang berkembang pesat saat ini khususnya era revolusi 4.0 yang begitu ramai diperbincangkan.Apakah benar bahwa dengan adanya era tersebut, keterampilan menulis semakin baik atau justru menjadi tantantangan tersendiri bagi calon-calon penulis. Oleh karena itu, tulisan ini akan memfokuskan pembahasan yang berkaitan dengan hal itu.

\section{METODE PENELITIAN}

Dalam mendapatkan hasil penelitian ini, penulis menggunakan metode studi kepustakaan yang dapat diartikan dengan penelusuran sumber-sumber bahan yang relevan dari permasalahan yang disampaikan.Oleh karena itu, penentuan sumber-sumber literasi yang tepat menjadi persyaratan utama dalam menemukan gambaran tentang kontribusi dan tantangan literasi digital dalam keterampilan menulis.Dengan demikian, sumber-sumber yang digunakan dalam tulisan ini adalah berupa sumber buku, sumber majalah, dan sumber kumpulan jurnal penelitianyang telah dibukukan dan yang relevan dengan ide yang termuat di dalam karya ini. 


\section{HASIL DAN PEMBAHASAN \\ Makna Kata Menulis}

Menulis seperti yang sudah umum diketahui adalah sebuah kegiatan untuk menuangkan ide-ide melalui atribut kebahasaan.Akan tetapi, pengertian menulis harus dimaknai secara luas agar pengertian ini tidak "jatuh" dalam pengertian yang sempit seperti hanya sekadar menuangkan ide semata melalui perangkat bahasa.Artinya, menulis harus memiliki tujuan-tujuan tertentu agar ide yang sudah dituliskan benar-benar bermakna bagi para pembacanya.Di kalangan penulis ternama atau bahkan di kalangan pegiat literasi, ada semacam semboyan atau semacam prinsip yang mampu untuk menggugah dan bahkan menjadi pemantik semangat untuk menulis. Istilah atau semboyan itu selalu dipegang teguh manakala saat penulis itu akan mengalami situasi "kedangkalan sumur ide" dalam proses menulisnya. Situasi itu sangat umum dirasakan setiap orang yang berkecimpung dalam tulis-menulis.

Terkait dengan semboyan atau istilah yang dimaksud, paling tidak ada dua yang sampai hari ini terus mengemuka.Pertama, ungkapan publish or perish. Ungkapan yang memberikan tujuan yang jelas untuk apa seseorang menulis. Jelas dalam ungkapan ini, seseorang menulis sebenarnya bertujuan untuk menunjukkan eksistensi dirinya lewat karya tulisannya. Sebaliknya, seseorang yang tidak ingin menulis maka selamanya ia tidak akan dapat dikenal oleh orang lain. Dengan kata lain, seseorang itu dapat dikatakan binasa dalam tataran ide. Jika dimaknai lebih mendalam, tujuan seseorang menulis singkatnya ingin menunjukkan "keabadian". Artinya, pengertian keabadian di sini lebih menekankan sebuah ide yang akan dapat meninggalkan kemanfaatan bagi orang lain bahkan sampai penulis itu sendiri pun sudah tiada. Idenya akan selalu dikenang oleh orang banyak. Sejalan dengan ini, pendapat salah satu penulis hebat diIndonesia pernah mengatakan "Orang boleh pandai setinggi langit, tetapi selama ia tidak menulis, ia akan hilang di dalam masyarakat dan dari sejarah. Menulis adalah bekerja untuk keabadian (Pramoedya AnantaToer" yang diambil dari salah satu tulisannya yang terkenal dengan judul "Rumah Kaca".Selain itu, salah satu penulis buku yang konsisten pembahasannya dalam Bahasa Indonesia juga pernah mengemukakan pendapatanya.Di dalam bukunya yang berjudul "99 Cara Mudah Menulis Karya Ilmiah", Kuntarto dan Putranto (2015: 1-3) memberikan paling tidak ada enam tujuan seseorang mengapa perlu menulis.Keenam tujuan itu adalah (1) menggapai keabadian, (2) pencarian kebenaran, (3) pembuktian diri dan eksistensi, (4) prestise atau gengsi, (5) publikasi dalam jurnal atau media tertentu, (6) syarat formal kenaikan JJA (khusus guru dan Dosen).

Tujuan (1) dari pendapat itu, sejalan dengan penjelasan sebelumnya bahwa memang alasan seseorang ingin menulis karena mengapai sebuah ide yang abadi yang dapat dikemudian hari dibaca, diingat, dikenang oleh orang lain meskipun dirinya sudah meninggal dunia. Tujuan ini jelas memberikan manfaat dalam menghidupkan eksistensi dirinya lewat ide dalam setiap karyanya. Tujuan (2) dari menulis dapat diartikan secara sempit bahwa seseorang ingin menulis karena ia ingin menemukan sendiri kebenaran-kebenaran tertentu yang kemudian ingin dibuktikan sejauh mana kebenaran itu akan berdampak luas bagi orang lain. Sebagai seorang penulis, biasanya akan ada rasa kepuasan tersendiri manakala 
berhasil menulis sebuah karya tulis ilmiah yang benar menyajikan penemuan kebenaran tertentu.

Tujuan (3) dari menulis lebih mengarah personalitas.Artinya, seseorang ingin menulis ingin lebih menunjukkan jati dirinya.Umumnya dalam menunjukkan eksistensi diri ada kewaspadaan yang patut diperhatikan agar tidak jatuh pada arah "kesombongan".Tujuan (4) dari menulis dapat diartikan sebagai bentuk psikologis penulis yang memang tidak hanya memandang kegiatan menulis itu hanya sekadar menuangkan ide agar dikenal atau eksis. Akan tetapi, lebih menekankan level keterkenalan atau popularitas sebagai penulis di mata penulis-penulis yang lain yang mungkin secara tema pembahasan sama. Pada posisi ini biasanya penulis yang satu dengan penulis yang lainnnya akan berlomba-lomba atau berkompetisi untuk menghasilkan tulisan yang terbaik sampai-sampai akan berambisi menjadi penulis dengan karya-karya terlaris (bestseller)

Tujuan (5) dari menulis dapat diartikan bahwa ada keinginan khusus untuk menerbitkan setiap karya tulisannya dalam wadah ilmiah yang benar-benar terverifikasi oleh badan-badan pengelola jurnal tertentu. Umumnya jurnal-jurnal tertentu terverifikasi melalui terdaftarnya di dalam sebuah instansi-instansi tertentu.Selanjutnya, tujuan (6) sejalan dengan tujuan (5) bahwa seseorang menulis untuk mendapatkan provit atau keuntungan dalam pengembangan kariernya di dalam dunia akademik seperti mendapatkan kenaikan pangkat, gelar, dan bahkan kenaikan tunjangan gaji seperti sertifikasi di dalam profesi guru dan dosen.

Kedua, ungkapan dari bahasa Latin "verba volent, scripta manent". Ungkapan itu dapat dimaknai sebagai sebuah nasihat penting bagi masyarakat luas bahwa pertuturan atau ucapan itu cenderung hilang begitu cepat, sementara tulisan itu akan cenderung lebih tetap atau abadi. Bila merujuk konteks di Indonesia, tampaknya ungkapan ini masih relevan mengingat banyaknya siswa atau mahasiswa yang lebih banyak melakukan dan menghidupi budaya bicara daripada budaya menulisnya.Hal ini mungkin juga tidak terlepas dari sejarah panjang bagaimana akhirnya sistem akasara atau tulisan itu di kenal di Indonesia.

\section{Tantangan Umum Calon Penulis}

Berdasarkan pengalaman penulis sendiri, kegiatan atau aktivitas menulis selalu memiliki tantangan-tantangan khusus. Akan tetapi, setiap calon penulis biasanya akan sama mengalami tantangan secara umum. Kemampuan melewati atau mengalahkan tantangan inilah yang kelak menjadikan seorang penulis pemula naik level menjadi seorang penulis profesional. Dengan kata lain, kemampuan melampaui tantangan umum itu yang kelak akan mewujudnyatakan tujuan-tujuan menulis yang telah disampaikan sebelumnya.

Tantangan itu menurut penulis paling tidak ada enam hal.Keenam hal yang dimaksud yaitu (1) Tidak ada niat atau gairah menulis, (2) ada niat, tetapi selalu merasa tidak tepat waktunya untuk menulis, (3) merasa tidak tahu apa yang akan ditulis (tataran ide), (4) takut salah, merasa tidak bermutu (tataran teknis dan konten), (5) pengaruh perhatian terhadap hal-hal yang tidak produktif, (6) tidak dapat memanfaatkan teknologi secara tepat guna.

Tantangan (1) yang umum dialami setiap orang bukan hanya sebagai calon penulis pemula adalah ketiadaan niat atau gairah untuk menulis.Pada tantangan ini biasanya sangat sulit untuk mengubah minat agar mau menulis.Hal pertama yang 
harus dilakukan adalah mengubah paradigma berpikirnya bahwa menulis itu sesuatu yang menyenangkan. Oleh karena itu, orang semacam ini harus diberikan contoh-contoh langsung yang mampu mengubah cara berpikirnya. Misalnya, mengarahkannya agar mau menulis apa yang berkesan yang dialaminya, entah itu berkaitan dengan kesukaan atau hobinya, entah itu juga berkaitan dengan perjalanan ke suatu tempat dan lain-lainnya.

Tantangan (2) pada tataran niat atau keinginan untuk menulis sudah ada, tetapi untuk merealisasikannya sangat sulit karena merasa tidak memiliki waktu yang tepat untuk menulis.Sebenarnya, alasan ini cukup berterima dengan akal sehat bila memang tingkat kesibukan kita sangat luar biasa. Namun, alasan ini akan menjadi sebuah klise karena memang tidak berani saja untuk memulai dan hanya beralasan tidak memiliki waktu yang tepat. Prinsip menulis biasanya mulai saja terlebih dahulu.Kita jangan memikirkan untuk mengambil waktu khusus agar mau menulis.Hal itu karena kalau hanya bergantung waktu kemungkinan besar justru menunggu-nunggu waktu itu yang benar-benar menghabiskan waktu.Saran atas persoalan seperti ini lebih baik jangan menunda-nunda waktu, saat di situ kemunculan ide saat itu pulalah kita menuliskannya.

Tantangan (3) pada tataran ide yang memang sama sekali tidak tahu apa yang hendak dituliskan. Tantangan seperti ini memang banyak dikeluhkan siswa atau pun mahasiswa karena sama sekali ide tulisan tidak ada. Merasa bahwa tidak ada permasalahan sehingga jika ingin menulis sama sekali tidak memiliki bekal tentang persoalan apa yang hendak dikemukakan. Sebagai solusinya, calon penulis harus benar-benar melakukan asketisme intelektual.Maksudnya seorang calon penulis harus melakukan tindakan-tindakan ilmiah untuk mendapatkan ide seperti tindakan merenung, membaca, dan membuat catatan-catatan kecil yang kemungkinan nanti sangat bermanfaat untuk kelancaran ide.

Selain itu, bagi calon penulis harusnya perlu mengingat prinsip "pengendapan ide" dan bukan "penenggelaman ide". Maksudnya adalah kebanyakan calon penulis akhirnya lupa pada ide yang pertama yang hendak dituliskan karena terlalu lama untuk tidak dituangkan dalam bentuk tulisan sehingga ide yang tadinya baik akan tenggelam begitu saja. Tantangan(4) pada tataran teknis dan konten juga dialami setiap calon penulis. Artinya, untuk menemukan tema yang cocok dituliskan rasanya ada kekurangpercayaan dari diri si penulis.Kekurangpercayaan itu biasanya terjadi karena secara tema masih ada keraguan dan juga dari teknis penulisan yang memang dapat melunturkan keyakinan untuk menulis. Hal itu karena setiap tulisan ilmiah yang akan dihasilkan selalu memiliki syarat khusus atau format khusus penulisan. Oleh karena itu, pada posisi ini memang baiknya calon penulis sudah memiliki gambaran format penulisan agar menambah motivasi untuk menulis sesuai yang dipersyaratkan.

Selain itu, solusi yang terbaik sebenarnya bagi calon penulis tidak terlalu mengkhawatirkan hal itu. Calon penulis harus memiliki prinsip "mengalir seperti air" yang ke mana arusnya diikuti saja terlebih dahulu karena di tengah-tengah perjalanan itu akan ditemukan pengalaman-pengalaman berharga yang dapat dipetik. Tantangan (5) yaitu pengaruh kekurangfokusan si calon penulis. Artinya, calon penulis belum mampu berkosentrasi penuh pada apa yang hendak dituliskan. Hal itu karena pikirannya masih dapat dipengaruhi oleh aktivitas atau kegiatan-kegiatan lain yang mungkin secara minat juga mengalahkan minat untuk 
menulis.Oleh karena itu, calon penulis harus memiliki sikap yang dewasa untuk bijak menggunakan waktu secara produktif agar kegiatan tulis-menulisnya dapat berlangsung dengan baik.

Terakhir yaitu tantangan (6) yaitu pengaruh ketidakefektifan dalam menggunakan teknologi.Tantangan semacam ini tentu sangat berkontribusi dalam kesulitan menulis karena biasanya lebih dipengaruhi fitur-fitur permainan yang ada di dalam teknologi itu.Solusinya adalah harus dapat menempatkan teknologi di bawah pengendalian diri.Dengan kata lain, teknologi harus "tunduk" pada diri kita bukannya diri kita yang "tunduk" pada teknologi.

\section{KorelasiKeempat Keterampilan Berbahasa}

Menulis hanyalah salah satu bentuk keterampilan berbahasa dari bentuk keterampilan berbahasa yang lainnya seperti menyimak, membaca, dan berbicara.Keterampilan menyimak dan membaca sendiri dikategorikan ke dalam bentuk keterampilan reseptif. Artinya, keterampilan dalam dua bentuk itu lebih dilakukan sebagai sebuah tindakan untuk menerima sebuah informasi saja. Sebaliknya, keterampilan menulis dan berbicara dikategorikan sebagai keterampilan produktif karena kedua bentuk keterampilan itu dapat membagikan sebuah informasi yang penting bagi orang lain.

Di antara keempat keterampilan itu, tentu keterampilan menulis yang paling sulit dilakukan karena memang membutuhkan tingkat kemampuan lebih sebab menulis tidak hanya sekadar menuangkan ide bagitu saja diperlukan sumbangsih dari ketiga keterampilan yang lainnya.Hal itulah mengapa keempat keterampilan itu tidak dapat terpisah-pisah.Keempatnya harus saling mendukung khususnya dalam keterampilan menulis.Hubungan itu secara sederhana dapat terlihat dari sumber-sumber ide atau permasalahan dapat diperoleh melalui kemampuan menyimak kita dari orang-orang cerdas atau orang-orang yang secara tingkat intelektualnya lebih tinggi dari kita sehingga dapat belajar dari ide itu. Selanjutnya, dari proses penelusuran ide melalui membaca buku-buku penulis hebat agar mendapat inspirasi penting. Bahkan ide-ide kita itu juga akan semakin matang apabila kita sering mengomunikasikannya pada sebuah forum diskusi tertentu sehingga para pendengar kita akan memberikan kritisi atas apa yang kita sampaikan dan kemudian hari akan sangat mendukung kesempurnaan tulisan kita.

Namun, menurut hemat penulis, salah satu bagian penting yang langsung dapat berkaitan dengan keterampilan menulis kita yaitu melalui keterampilan membaca.Terlebih di tengah-tengah kemudahan pencarian sumber atau akses informasi yang begitu mudah dapat memberikan kontribusi terhadap kualitas tulisan kita.Menurut Howard (2016: 31) "Jika ada estimasi waktu satu jam, pergunakan setengah jam untuk membaca dan setengah jam lagi untuk merenungkan lalu menuliskannya kembali. Pendapat ini sangat tepat karena kebanyakan di antara calon penulis hanya mungkin "rajin" membaca atau menghabiskan banyak waktu untuk membaca.Akan tetapi, tidak menyisihkan waktu untuk merenungkan dan bahkan menuliskannya kembali dalam bentuk pernyataan sendiri. Oleh karena itu, kita harus berlatih untuk melakukan parafrase kalimat dari apa yang kita baca agar lebih melekat di memori kita. Hal itu sejalan dengan teori umum bahwa tingkat memori seseorang tidaklah sama. Ada yang daya ingatnya sangat tajam dan ada juga yang hanya beberapa menit atau beberapa jam lupapada apa yang telah dibacanya. 


\section{Literasi Digital dan Hubungannya dengan Menulis}

Sejatinya, di era perkembangan teknologi informasi saat ini, kita cukup banyak mendengar istilah-istilah yang berkaitan dengan kata literasi.Misalnya, kita sebut saja literasi bahasa, literasi numerasi, literasi sains, literasi finansial, literasi budaya dan kewargaan, dan tentunya yang paling sering kita dengarkan yaitu literasi digital.Oleh sebab itu, jika mencermati istilah literasi digital yang sudah banyak dibicarakan, tentulah selalu menarik untuk diketahui bagaimana konsep atau hakikat dasarnya serta bagaimana hubugannya dengan kegiatan menulis. Untuk mengkaji lebih jauh istilah itu, perlulah untuk menelusuri makna istilah itu secara sederhana.Hal pertama yaitu istilah literasi yang secara etimologis berasal dari bahasa Latin yaitu literatus yang berarti orang yang belajar.

Berdasarkan pengertian ini, konsepnya sangat luas sebab orang yang belajar dapat diartikan sebagai orang yang selalu meningkatkan pemahamannya agar lebih memahami sesuatu sehingga perilaku belajar akan diterapkan dalam kehidupannya. Belajar dapat diartikan sebuah proses yang secara terus-menerus untuk memperoleh pengetahuan baru. Segala upaya dan daya akan dilakukannya demi menambah pemahamannya secara baik. Hal kedua yaitu istilah digital yang secara etimologis berasal dari bahasa Yunani yaitu kata digitus yang berarti jarijemari.Dari pengertian ini, kita dapat mengatakan bahwa data-data apapun sudah bertumpu pada kecepatan dan kemampuan jari-jemari kita dalam mengaktifkan dan menelusuri sumber-sumber yang ada dalam media digital.Oleh karena itu, istilah literasi digital dalam kerangka keterampilan berbahasa dapat diartikan sebagai kemampuan setiap individu dalam menggali informasi sebanyak mungkin dari sumber-sumber tertentu melalui kemampuan menyimak, membaca, menulis, dan berbicara dan kemudian memproduksinya kembali melalui terapan teknologi tepat guna.

Pengertian ini sejalan dengan pendapat Gilster (1997) dan Riel (2012)dalam tulisan Husna dan Rohmiyati (2017: 6) yang mengemukakan bahwa literasi digital adalah kemampuan menggunakan teknologi dan informasi dari piranti digital secara efektif dan efisien dalam berbagai konteks seperti akademik, karier, dan kehidupan sehari-hari.Literasi digital sendiri dalam hubungannya dengan menulis tentulah sebuah kemampuan untuk memahami keanekaragaman sumber informasi dari jejak-jejak digital yang dapat dimanfaatkan mencari sumber-sumber tulisan khususnya sebagai sumber pemantik dalam penemuan ide dalam tulisan. Dengan sederhana dapat dikatakan bahwa literasi digital dalam kegiatan menulis akan menjadi satu wahana atau media yang menyediakan segala informasi yang kita butuhkan. Tujuannya sangat baik yaitu paling tidak calon penulis akan mengetahui sejauh mana posisi permasalahan yang akan ditulis apakah sudah pernah dibicarakan penulis lain atau belum.

Jika seandainya sudah pernah dibicarakan dalam tulisan orang lain, di sini kita harus mencari poin yang berbeda dari yang sudah ada. Gunanya agar tulisan kita tidak terkesan mengulang tulisan yang sudah ada sebab kemungkinan besar tulisan orang lain sudah terlebih dahulu terkenal atau banyak dibaca oleh orang lain juga. Oleh karena itu, keunikan dan gaya khas penulisan kita akan menambah daya tarik pembaca lainnya. 


\section{Tantangan Menulis di Zaman Milenial}

Zaman milineal dan era revolusi 4.0 saat ini dapat dikatakan sebuah zaman yang seutuhnya sumber-sumber sudah berbasis digital.Sumber yang sudah berbalik bentuk dari sumber konvensional menjadi sumber virtual yang setiap saat dapat ditemukan dengan kecepatan yang maksimal.Oleh karena itu, sejatinya pencarian sumber itu tidak sulit lagi.Akan tetapi, muncul sebuah tantangan yang sangat serius jika berkaitan dengan pengelolaan sumber secara baik.Hal itu sangat berkaitan dengan keterampilan menulis.Seorang calon penulis harus betul-betul menanamkan jiwa yang berintegritas dalam penelusuran sumber-sumber dan bahkan pemakaian sumber-sumber secara valid agar nantinya terhindar dari masalah plagiat.Karena di dalam dunia akademik, khususnya kegiatan tulismenulis, plagiat merupakan "musuh" dalam akademik. Tindakan curang seperti itu baiknya dihindari dan dihilangkan dalam setiap benak calon penulis.

Berkaca dari perkembangan teknologi di era ini, tantangan calon penulis dalam setiap aktivitas karya tulisnya paling tidak akan memperlihatkan bahwa kemanusiaan kita di zaman ini sudah bergeser. Dahulu kemanusiaan manusia yang dikenal dengan sebutan homo sapiens atau makhluk yang berpikir, makhluk yang cerdas secara pemikiran. Manusia yang selalu senang untuk melakukan asketisme intelektual kini sudah bergeser dalam kemanusiaan kita yang disebut dengan homo digitalis. Manusia yang sangat bergantung pada penyediaan data-data yang virtual. Dengan kata lain, manusia yang sudah dimanjakan tanpa harus lelah untuk melakukan aktivitas berpikir secara mendalam. Walaupun untuk menjembatani hal itu, manusia juga tidak terlepas dari kemanusiaannya yang disebut dengan homo gramaticus atau manusia yang secara natur memiliki kecerdasan atau kemampuan berbahasa.

Oleh karena itu, manusia tentu harus menggunakan kecerdasan bahasanya dalam mengaktualisasikan sumber-sumber data yang bersifat virtual. Hal itu karena dapat disebutkan bahwa tantangan menulis di era ini adalah manusia akan semakin kreatif. Dengan arti kata, setiap calon penulis akan sangat memungkinkan mengembangkan ide yang semakin menarik dan tajam pada setiap tulisannya. Akan tetapi, tantangan negatifnya justru calon penulis akan berpikir instan dan melakukan tindakan kecurangan dalam tulisannya. Di sinilah peran kecerdasan literasi perlu dimiliki setiap calon penulis agar tidak terjebak dalam informasi yang begitu banyak dan tidak mampu memilah, memilih, dan menentukan informasi mana yang tepat untuk dikutipnya.

Kondisi itu sangat sejalan dengan hal yang disampaikan oleh Hardiman (2018:20) yang mengatakan bahwa hampir setiap saat kita berhubungan dengan telepon genggam. Kita mengecek SMS, pesan Whatshapp, cuitan Twitter, mengetik pesan, mengunggah atau mengunduh gambar, video, atau meme untuk meresponsnya. Gawai bukan sekadar barang yang kita pakai.Kita bermain dengannya dan bahkan kita berpikir bersamanya.Dunia kita hari ini penuh cerita yang berasal dari pergaulan kita dengan gawai sampai-sampai sulit membedakan antara yang kita pikirkan dengan yang "dipikirkan" telepon pintar.

Mencermati pendapat itu, jelas Hardiman ingin mengatakan bahwa memang kemanusiaan kita saat ini sangat tergantung dengan teknologi yang secara kasatmata agak sulit menentukan apa yang benar-benar ide dari hasil pemikiran seseorang dan apa yang benar-benar ide yang dihasilkan oleh data-data 
virtual. Di sinilah permasalahan originalitas tulisan harus tetap dipertahankan oleh calon penulis agar tulisan-tulisan yang dihasilkannya tidak sekadar mengutip informasi dari media digital. Selain itu, tantangan calon penulis yaitu umumya kegiatan untuk menulis akan sulit dilakukan karena dengan adanya tekonlogi yang begitu canggih dapat mengalihkan perhatian calon penulis sehingga ada rasa keengganan atau kemalasan dalam menulis. Oleh karena itu, waktunya akan banyak terbuang dan asyik untuk diri sendiri sampai tidak peduli dengan lingkungannya. Istilah inilah yang sering dikenal dengan sebutan phubbing.Kata itu dapat diartikan secara gamblang sikap individu yang merasa bangga dan senang atas apa yang dilakukannya sendiri bersama dengan gawainya.

Bahkan tantangan lainnya yang harus juga diperhadapkan bagi calon penulis yaitu tulisan-tulisan yang dihasilkan kemungkin besar sangat terpengaruh dalam penyajian data-data yang tidak akurat dalam tulisan. Terlebih tulisan itu tidak dilakukan secara cermat sehingga data-data yang fiktif. Oleh karena itu, tulisan itu akan terpapar hoaks yang begitu sulit untuk dibendung. Calon penulis harus menyadari hal ini agar tulisan-tulisan yang dihasilkan betul-betul menjadi keakuratan data yang diambil dari sumber-sumber digital.Hal itu karena tujuan menulis bukan untuk menciptakan tulisan-tulisan yang tidak dapat dipertanggungjawabkan, melainkan tulisan-tulisan yang benar-benar dapat dibuktikan kebenarannya dan juga tentunya harus memenuhi asas manfaat bagi para pembacanya.

\section{Menuangkan Ide dalam Bentuk Karya Tulis}

Calon penulis banyak yang bingung untuk memulai tulisannya. Kebingungan itu sebenarnya termasuk pada level penuangan ide yang seperti apa yang hendak dituliskannya. Padahal jika berbicara penuangan ide dalam bentuk karya tulis ada banyak macam atau jenisnya.Menurut Kuntarto dan Putranto (2015:10-11) dapat dipahami bahwa setidak-tidaknya penuangan ide dapat diklasifikasikan dalam tiga kategori yaitu (1) cara penuturan, (2) bentuk pertuturan, dan (3) tujuan pertuturan. Untuk kategori yang pertama, seorang calon penulis dapat menuangkan ide melalui pola pengembangan paragraf atau alinea seperti menuangkan ide malalui ciri narasi, deskripsi, argumentasi, persuasi, dan eksposisi.Bahkan melalui pola pengembangan paragraf lainnya seperti perbandingan, pertentangan, analogi, ilustrasi, definisi, prosedural, sudut pandang dan lain-lain.

Kategori yang kedua, calon penulis dapat menuangkan ide melalui tulisantulisan yang bersifat ilmiah dan nonilmiah. Misalnya, khusus yang ilmiah, calon penulis dapat menuangkan ide tulisannya dalam bentuk makalah, laporan bab, esai, skripsi, tesis, dan disertasi serta bentuk-bentuk yang lainnya. Sebaliknya, tulisan-tulisan nonilmiah dapat dituliskan dalam bentuk pendekatan sastra apakah genre puisi, cerpen, drama, prosa, dan lain-lain.Kategori ketiga, calon penulis dapat menuangkan ide melalui tulisan-tulisannya yang memiliki tujuan tertentu seperti hanya sekadar menjelaskan suatu fenomena tertentu atau menjelaskan permasalahan tertentu, ingin memberikan semacam sugesti pada pembaca, memberikan sindiran-sindiran tertentu, memberikan kritik yang bersifat membangun, dan lainnya.

Calon penulis yang menyadari hal itu, umumnya calon penulis tidak akan berkutat pada pertanyaan bagaimana bentuk penuangan ide yang ingin dituliskan. Oleh karena itu, pada posisi ini, seorang calon penulis sudah harus memutuskan 
bentuk tulisan seperti apa yang hendak dihasilkan sehingga penuangan ide dapat terlaksana dengan baik. Keberanian penulis diharapkan mampu menutupi keraguan atas ide yang hendak dituliskan akan menjadi satu langkah yang positif dalam memulai setiap tulisannya.

\section{Pencarian Sumber dan Sitasi}

Tantangan yang tidak kalah penting dari apa yang sudah paparkan dalam keterampilan menulis yang harus diingat setiap calon penulis dan bahkan setiap penulis-penulis terkenal adalah pengenalan sumber-sumber informasi secara virtual dan bagamana cara menuliskan sumber-sumber yang tepat atau sitasi yang benar. Seperti yang sudah dikemukakan sebelumnya, Era Revolusi Industri 4.0 ini menjadikan sumber-sumber informasi sudah bergeser dengan begitu cepat sehingga tingkat kedinamisannya lebih lentur.Oleh karena itu, dibutuhkan kepiawaian dari calon penulis agar dalam pengutipan dan pemberian sitasi harus dilakukan secara bertanggungjawab.Bentuk sitasi yang umum dapat diperoleh dari salah satunya dalam bentuk $e$-book dan bahkan jurnal-jurnal ilmiah lainnya yang tersedia di dalam dunia internet.

Calon penulis harus menguasai cara mengutip yang tepat melalui konsep kutipan-kutipan yang tepat baik kutipan secara langsung maupun kutipan tidak langsung atau sering dikenal dengan sebutan parafrase kalimat. Karena melalui cara pengutipan yang baik di dalam batang tubuh tulisan (catatan perut), akan menggambarkan tulisan itu benar-benar merupakan argumen originalitas dari si penulis atau sebenarnya pendapat itu diambil dari pendapat para ahli.

Selanjutnya, hal itu akan terlihat saat calon penulis memberikan sitasi yang tepat atas apa yang dikutipnya. Di sinilah diperlukan pengenalan jenis-jenis sitasi agar memperkaya cara penulisan daftar pustaka atau bibliografi dalam tulisannnya. Secara umum ada beberapa model sitasi yang digunakan tergantung ketentuan seperti apa yang hendak diberikan. Misalnya, ada jenis atau model sitasi Harvad Style, CMOS (The Chicago Manual of Style), model APA (American Psychological Association), model MLA (The Modern Langguage Association), dan model Turabian Style. Semua model sitasi itu memiliki aturannya masingmasing.Jika calon penulis ingin membuat sitasi seperti itu, harus dipelajari terlebih dahulu agar sumber sitasinya tepat.Oleh karena itu, jika data-data yang sudah bersifat vitual disajikan, paling tidak ada tiga hal yang harus diingat yaitu Tanggal akses (unduh) dan alamat web atau URL (Uniform Resource Locator ) dan juga nama penulis (kreator ide). Ketiga hal itu nantinya akan tampak di dalam penulisan sitasi yang tepat khususnya dalam kutipan dan daftar pustaka.

\section{KESIMPULAN DAN SARAN}

Menulis memang harus diakui suatu tindakan penuangan ide yang tidak mudah dilakukan dibutuhkan niat dan pemahaman tentang unsur-unsur penulisan yang tepat.Terlebih jika diperhadapkan dengan Era Revolusi Industri 4.0 yang menyediakan begitu banyak data dan sumber-sumber ide dalam tulisan.Di sinilah diperlukan kepekaan dan sikap yang jujur dalam menuliskan sertiap ide yang hendak sampaikan agar nantinya ide itu tidak dianggap hanyalah hasil dari penelusuran dari ide-ide yang sudah tersedia melalui media digital.

Kekhasan dan keunikan tulisan perlu dipertahankan dengan tantangantantangan yang ada.Calon penulis harus menguasai unsur-unsur kebahasan dalam penulisan khususnya dalam pengutipan dan sitasi yang benar serta 
mengembangkan tulisan melalui pola-pola pengembangan paragraf yang diingkan.Dalam praktik pengajaran keterampilan bahasa, sudah waktunya para pengajar memperkenalkan cara-cara yang pantas dalam menulis terlebih dalam menulis yang berkategorikan karya tulis ilmiah. Pelajar atau mahasiswa harus menyadari keberadaan teknologi dan informasi saat ini sangat berkontribusi besar dalam penelusuran ide-ide yang akan dikembangkan di dalam tulisan. Namun, sebaliknya tantangannya justru akan terjadi manakala calon penulis termasuk pelajar atau mahasiswa menggunakan teknologi informasi dengan cara-cara yang curang atau dengan tindakan yang melakukan malakademik. Di sinilah pentingnya pengenalan literasi digital kepada para calon penulis yang termasuk di dalamnya para pelajar dan mahasiswa agar dapat menghasilkan tulisan-tulisan yang bermutu dan bermanfaat bagi masyarakat pembacanya.

\section{DAFTAR PUSTAKA}

Hardiman, Frangky Budi. 2018. "Heidegger di Zaman Telepon Genggam”. Dalam Basis Nomor 07-08. Yogyakarta

Hendricks, Howard G. 2016. Mengajar untuk Mengubah Hidup.(Terj). Yogyakarta: Yayasan Gloria.

Husna, Jazimatul dan Rohmiyati,Yuli. 2017.Peran Sekolah dan Guru dalam Membangun Pendidikan Siswa melalui Literasi Media Digital. JurnalAntologi Literasi Digital. Yogyakarta: Azyan.

Kuntarto, Niknik dan Putranto. 2015. 99 Cara mudah menulis karya ilmiah. Yogyakarta: Indopublika.

Toer, Pramoedya Ananta. 2007. Rumah kaca. Lentera Dipantara. 